\title{
Total mercury level in tissues of commercial mammalian species (wild boar, moose) of the Russky Sever National Park (North-West of Russia)
}

\author{
Liubov Eltsova*, Elena Ivanova \\ Cherepovets State University, Biology Department, 162600, 5 Lunacharsky Pr., Cherepovets, \\ Vologda region, Russia
}

\begin{abstract}
Bioaccumulation of mercury in the food chain can pose a threat to human health. Therefore, in our article, we obtained data on the concentrations of mercury in the tissues of wild animals, which are a food resource for humans. We determined the mercury concentrations in liver, kidneys, muscles and hair of wild boar and moose, which are consumed by the population of the Russky Sever National Park. The average mercury concentrations in moose tissues ranged from $0.004 \mathrm{mg} / \mathrm{kg}$ wet weight in muscles to $0.079 \mathrm{mg} / \mathrm{kg}$ wet weight in kidneys. The average concentrations of mercury in boar tissues ranged from $0.136 \mathrm{mg} / \mathrm{kg}$ wet weight in wool to $0.711 \mathrm{mg} / \mathrm{kg}$ wet weight in kidneys. The main trends of mercury bioaccumulation in the tissues of moose and wild boar were determined.
\end{abstract}

\section{Introduction}

Mercury $(\mathrm{Hg})$ is a global toxic pollutant that tends to bioaccumulate and biomagnify in the food chain $[1,2,3,4]$. The toxic properties of mercury make it a serious threat to the environment and living organisms [5]. People who occupy the highest trophic level are uniquely exposed to mercury they take from food. The accumulation of mercury in animals that are a food resource for humans remains an urgent problem of our time $[6,7]$.

The Russky Sever National Park is a specially protected natural area in the North-West of Russia, where hunting is allowed. Local residents traditionally eat wild boar and moose meat, so the presence of potentially toxic elements, such as mercury, can lead to increased impact consumers of these animals ' organs. Therefore, it is important to assess the mercury concentrations in the tissues of these species of commercial mammals of the Russky Sever National Park, as well as to check possible trends of the bioaccumulation of this toxic metal in their tissues.

\footnotetext{
*Corresponding author: khabarovals@yandex.ru
} 


\section{Materials and methods}

The study was conducted from 2014 to 2019 on the territory of the Russky Sever National Park (Fig. 1).

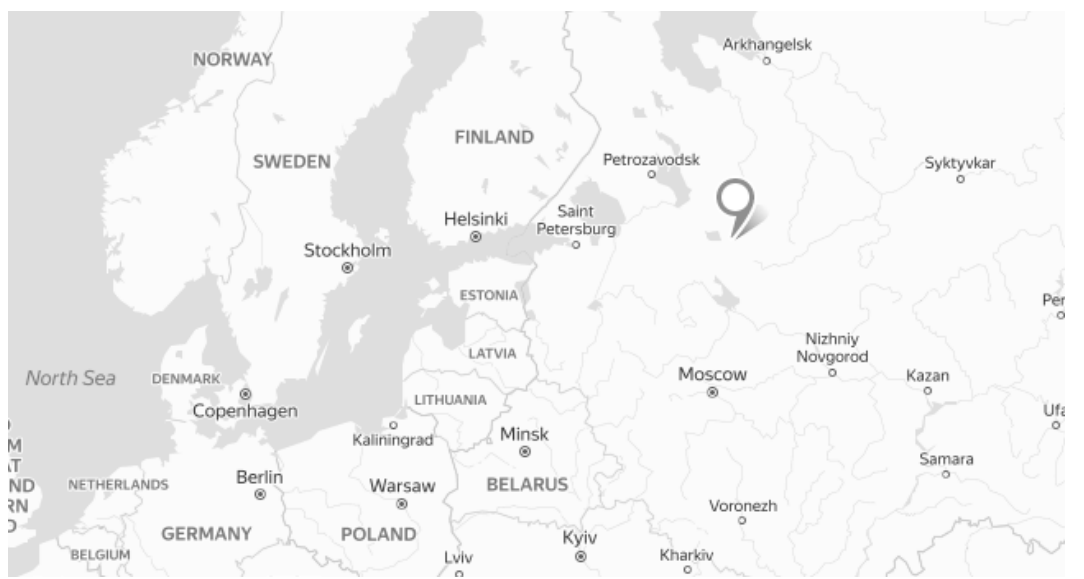

Fig. 1. The research area is the Russky Sever National Park (the icon marks the place of animals capture) https://yandex.com/map-constructor/

Mercury was measured in liver, kidneys, muscles, and fur of wild boar (Sus scrofa) and moose (Alces alces). The 191 tissue samples from the 105 individuals were analyzed for a presence of mercury: 25 wild boars, 80 moose (Table 1 ).

The animal tissue samples were provided by hunters licensed to hunt wild species of mammals. Animal tissue samples were collected, placed in plastic bags, frozen and stored at a temperature of $-16{ }^{\circ} \mathrm{C}$. The metal concentrations was determined by according to the method of GOST R 54639-2011 "Food and animal feed. Determination of mercury by atomic absorption spectrometry based on the Zeeman effect" using the mercury analyzer RA-915M with the prefix PYRO-915+ (the sensitivity of the device is $0.001 \mathrm{mg} / \mathrm{kg}$ ) [8]. Samples of animal tissues weighing $20-50 \mathrm{mg}$ were added to the thermolysis cell to determine the total mercury concentrations. The samples were burned down at a temperature of $300^{\circ} \mathrm{C}$ for 1-3 minutes. The measurement accuracy was controlled using certified biological material DORM-4 and DOLT-5 (Institute of Environmental Chemistry, Ottawa, Canada).

The results of measurements of mercury concentrations in tissues ( $\mathrm{mg} / \mathrm{kg}$ wet weight) are presented in the text in the form of the mean and the errors of mean $(\mathrm{x} \pm \mathrm{mx})$, in the table the data is presented in the forms of the mean, median, minimum and maximum values, standard deviation and errors of mean. The significance of differences in mercury concentrations between Mann-Whitney test at $p<0.05$, and the significance of differences in mercury concentrations between tissues was estimated using the Kruskal-Wallis test at $p$ $<0.05$.

\section{Results}

The content of mercury in tissues of moose and wild boar varies from less than 0.001 $\mathrm{mg} / \mathrm{kg}$ wet weight for kidney and muscle of wild boar (and for all tissues of moose) to $2.163 \mathrm{mg} / \mathrm{kg}$ in the kidneys of wild boar (Table 1, fig. 2). Mercury concentration in all the studied tissues of wild boar were significantly higher than in the corresponding tissues of moose at $\mathrm{p}<$ of 0.05 (Table 1, fig. 2). 
Table 1. Mercury concentrations in the tissues of moose and wild boar of the Russian North National Park

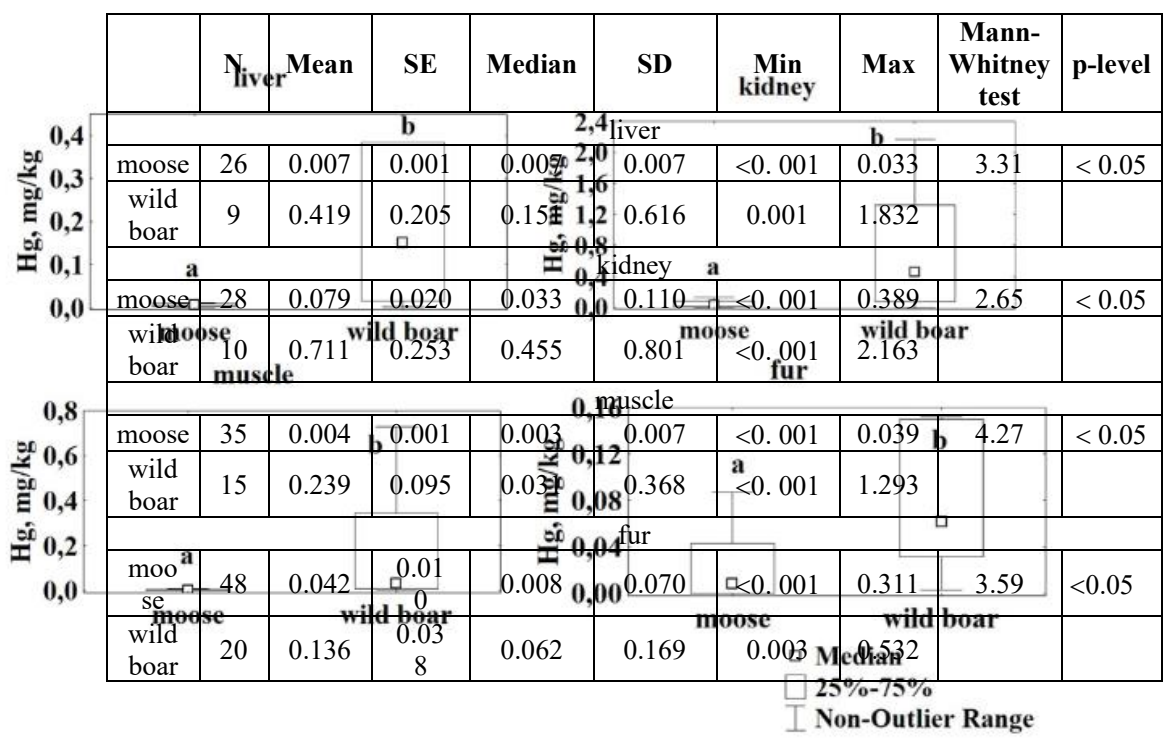

Fig. 2. Mercury concentrations in tissues of moose and wild boar of the Russian North National Park

The mercury concentration in moose tissues decreases in the following order: kidney $>$ hair $>$ liver $>$ muscle (Fig. 3). The mercury concentration in moose kidneys is significantly higher than the mercury concentrations in liver, muscles and fur, and the mercury concentration in fur is significantly higher than in muscles at $\mathrm{p}<0.05$ (Fig.3).

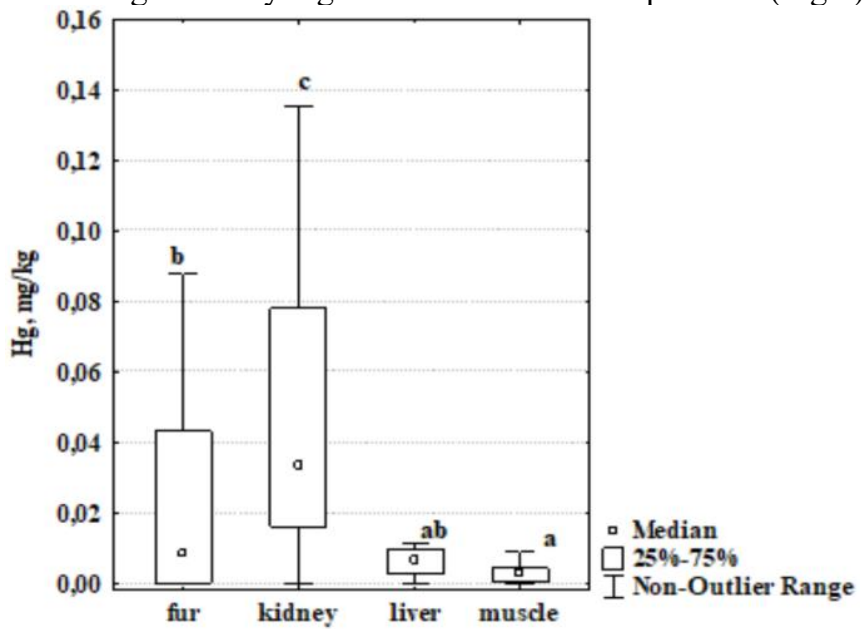

Fig. 3. Mercury concentrations in different tissues of moose of the Russian North National Park

The concentration of mercury in tissues of the boar decreases in the series: kidney $>$ muscle $>$ liver $>$ fur (Fig. 4). At the same time, the concentrations of mercury in kidneys, liver, muscles and hair of boar do not significantly differ from each other at $p>0.05$ (Fig.4). 


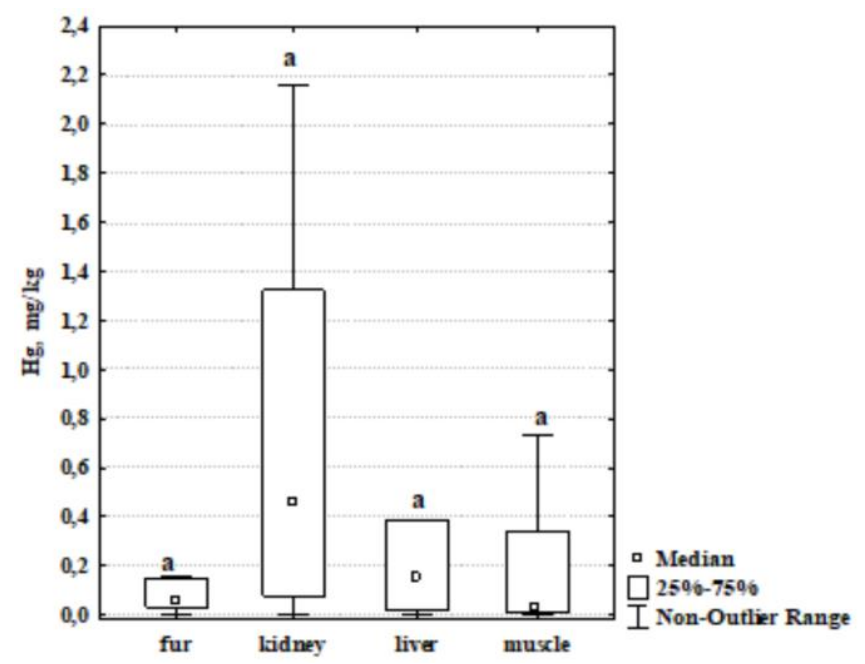

Fig. 4. Mercury concentrations in different tissues of wild boar of the Russian North National Park

\section{DISCUSSION}

Significant differences in mercury concentrations in tissues of moose and wild boar are explained by the difference in the range of animal nutrition: moose is a herbivore, wild boar is an omnivore. The average mercury concentration in moose tissues (liver: $0.007+0.001$, muscle: $0.004+0.001$, kidney: $0.079+0.02 \mathrm{mg} / \mathrm{kg}$ wet weight) is $1.5-2.5$ times higher than in the corresponding tissues of moose (Alces americanus) in Mackenzie Valley (Dehcho region, Northwest Canada) (liver: 0.005 , muscle: 0.002 , kidney: $0.03 \mathrm{mg} / \mathrm{kg}$ wet weight) [8]. At the same time, the average concentration of mercury in muscles of moose traditionally eaten by the local population $(0.004+0.001 \mathrm{mg} / \mathrm{kg}$ wet weight $)$ is comparable to the level of total mercury in traditional foods of the Bigstone Cree tribe in Alberta, Canada $(0.003 \pm 0.001$ raw weight $)$ [9].

The average mercury concentration in wild boar tissues of the Russky Sever National Park (liver: $0.419+0.205$, kidneys: $0.711+0.253 \mathrm{mg} / \mathrm{kg}$ wet weight) is higher than the mercury concentrations determined by dry weight in the corresponding wild boar in nature reserves and national parks of Poland: unpolluted area within the Mazurski Landscape Reserve (liver: 0.043, kidneys: $0.321 \mathrm{mg} / \mathrm{kg}$ dry weight), agricultural land within Snieznicki Landscape Park (liver: 0.043, kidney: $0.314 \mathrm{mg} / \mathrm{kg}$ dry weight), non-industrial area near Bieszczadzki National Park (liver: 0.101, kidney: $0.729 \mathrm{mg} / \mathrm{kg}$ dry weight) [10].

At the same time, the concentration of mercury in the liver $(0.419+0.205 \mathrm{mg} / \mathrm{kg}$ wet weight $)$ and muscles $(0.239+0.095 \mathrm{mg} / \mathrm{kg}$ wet weight $)$ of wild boar in Northwestern Russia is an order of magnitude higher than in the liver of wild boar in Slovakia (liver: 32, muscle: $11 \mathrm{mcg} / \mathrm{kg}$ ) [11], Spain (liver: 6.8, muscle: $4.3 \mathrm{mcg} / \mathrm{kg}$ ) [3].

The paper [10] examines the usefulness of wild boar fur (Sus scrofa) as a non-invasive indicator of mercury contamination. According to the results of our studies, the concentration of mercury in boar hair does not significantly differ from the concentration of mercury in other studied tissues, so the boar hair of the Russky Sever National Park can be used as a non-invasive indicator of mercury contamination. Mercury concentration in boar hair higher $(0.136+0.038 \mathrm{mg} / \mathrm{kg}$ wet weight $)$ than mercury concentrations determined by dry weight in the corresponding boar tissues in nature reserves and national parks in Poland: unpolluted area within the Mazurski Landscape Reserve $(0.065 \mathrm{mg} / \mathrm{kg}$ dry weight $)$, 
agricultural land within the Snieznicki Landscape Park $(0.103 \mathrm{mg} / \mathrm{kg}$ dry weight), nonindustrial area near Bieszczadzki National Park (0.343 mg/kg dry weight) [10].

\section{CONCLUSION}

Mercury concentrations in tissues of moose and wild boar of the Russky Sever National Park are higher than in the corresponding tissues of animals in Europe and Canada. The mercury concentration in all the studied boar tissues is significantly higher than in the corresponding moose tissues. The maximum concentrations of mercury in both wild boar and moose were determined in the kidneys. Boar fur does not significantly differ in the concentrations of mercury from other organs, therefore, it can be used as a non-invasive method for assessing mercury contamination.

\section{References}

1. J. Xu, M. Buck, K. Eklöf, O.O. Ahmed, J. K. Schaefer, K. Bishop, U. Skyllberg, E. Björn, S. Bertilsson \& A.G. Bravo, Sci. Rep, 9 (1), 518 (2019)

2. J. T. Ackerman, J. A. Fleck, C. A. Eagles-Smith, M. Marvin-DiPasquale, L. WindhamMyers, M. P. Herzog, \& H. L. McQuillen, ET\&C, 38(10), 2178-2196 (2019)

3. J. J. Berzas Nevado, R. C. Rodríguez Martín-Doimeadios, R. Mateo, N. Rodríguez Fariñas, J. Rodríguez-Estival, \& M. J. Patiño Ropero, Environ. Res., 112, 58-66 (2012)

4. J. Rodríguez-Estival, M. E. Ortiz-Santaliestra, \& R. Mateo, Environ. Res., 181 (2020)

5. T. W. Clarkson, \& L. Magos, Crit. Rev. Toxicol., 36(8), 609-662 (2006)

6. M. Durkalec, J. Szkoda, R. Kolacz, S. Opalinski, A. Nawrocka, J. Zmudzki, Int. J. Environ. Res., 9 (2015)

7. T. Florijancic, S. Ozimec, D. Jelkic, N. Vuksic, N. Bilandzic, A. Gross Boskovic, I. Boskovic J. Environ. Prot. Ecol., 16 (2015)

8. N.C. Larter, C.R. Macdonald, B.T. Elkin, D.C.G. Muir, X. Wang, Analysis of Cadmium, Mercury and Other Elements in Mackenzie Valley Moose Tissues Collected from 2005 to 2016 (2018)

9. N. Golzadeh, B. D. Barst, N. Basu, J. M. Baker, J. C. Auger, \& M. A. McKinney, Chemosphere, 250 (2020)

10. M. A. Sobańska, Sci. Total Environ., 339(1-3), 81-88 (2005)

11. J. Gasparik, L. J. Binkowski, A. Jahnatek, P. Smehyl, M. Dobias, N. Lukac, M. Blaszczyk, M. Semla, \& P. Massanyi Biol., Trace Elem. Res., 177(2), 258-266 (2017) 